\title{
ELECTIONS AND PARLIAMENTARY OVERSIGHT IN BOTSWANA
}

\author{
Onkemetse B Tshosa
}

\author{
Dr Onkemetse B Tshosa is a Senior Lecturer in Law, \\ Head of the Department of Law at the University of Botswana, \\ Judge of the SADC Tribunal and a Member of the \\ University's Democracy Research Project \\ P / Bag UB 00705, Gaborone, Botswana \\ Tel: +267 355 2344; Fax: +267 3170706 \\ TSHOSAOB@mopipi.ub.bw
}

\begin{abstract}
Botswana's Legislature plays a significant role in overseeing the electoral system and ensuring that it adheres to the minimum basic tenets of democracy such as free and fair, competitive elections and that the vast majority of eligible voters participate in the whole electoral processes. The main piece of legislation the National Assembly has enacted is the Electoral Act, which provides for the general administration of elections and electoral processes, electoral institutions, requirements for voting, electoral offences and sanctions. The Electoral Act has been supplemented and augmented by constitutional amendments, notably the establishment of the Independent Electoral Commission and the promulgation of regulations. The former, in particular, has, by and large, addressed the issue of free and fair elections. The paper concludes that these legislative initiatives have contributed to the consolidation of liberal democracy in the country and that Parliament has a still greater role to play in ensuring a free and fair electoral system.
\end{abstract}

\section{INTRODUCTION}

Free and fair elections engender confidence in a country's political system and there is general recognition and consensus that Botswana has an entrenched democratic culture of competitive electoral process and responsive government (Roberts et al 2000, p 1; Otlhogile 1994, p 222). Thus, by and large, the country's liberal democracy is increasingly consolidating. This is due, in large measure, to 
the role of Parliament. ${ }^{1}$ Parliament in Botswana has ensured that elections are free and fair through its robust legislative and regulatory activities. It has played a major role in ensuring that the electoral process is democratically conducted. The aim of this paper is to examine and analyse the role and function of the National Assembly in the democratic process. It discusses the functions of the Assembly in relation to the electoral process and particularly the manner in which it provides, and has provided, oversight of this process. The paper concludes by arguing that Parliament has a role to play in enhancing and ensuring a fair, free and democratic election.

\section{ESTABLISHMENT OF THE NATIONAL ASSEMBLY}

The National Assembly is established by the Constitution of Botswana (ss 55, 5777), which provides that 'there shall be a Parliament of Botswana which shall consist of the President and a National Assembly' (Constitution s 57). The National Assembly consists of 57 elected members (Constitution s 58(2)(a)) ${ }^{2}$ and four specially elected members (s 58(2)(b)). In addition, the speaker and deputy speaker are also members of Parliament (ss 59(1), 60(1)). Parliament is therefore accorded constitutional status in the legal system.

According to the Constitution a person qualifies to be elected as a member of the National Assembly firstly, if he or she is a citizen of Botswana. The issue of citizenship is regulated by the Citizenship (Amendment) Act of 1995, which amends the 1982 and 1987 Citizenship Acts. The latter effectively denied citizenship to children of Batswana women married to foreigners while Batswana men who married non-citizens could pass on their citizenship to their children. The net effect of this was that children of Batwsana women did not qualify for certain rights, including the right to stand for Parliament.

The Citizenship Act was challenged in Attorney General of Botswana vs Unity Dow (BLR 1992, p 119 (Court of Appeal)), in which the respondent successfully argued, inter alia, that the Act prevented her from passing on her citizenship to her children simply because she was married to a foreigner. Parliament exercised its legislative role and amended the Citizenship Act in 1995.

A further qualification is that in order to be elected to the National Assembly a person should be 18 years old (Constitution s 61(b)). The original age limit of 21 was changed (s 67(1)(b)) after the 1997 national referendum which recommended that it should be reduced.

\footnotetext{
In this paper the term Parliament is used interchangeably with National Assembly and Legislature.

2 In the last delimitation exercise the number of elected members was increased from 40.
} 
Any person standing for election to the National Assembly should be qualified to register as a voter (s 61(c)). Further, aspiring member of the legislature should be able to speak, and, unless incapacitated by blindness or other physical cause, to read English well enough to take an active part in the proceedings of the Assembly (s 61(d); Nsereko 2001, p 122). English is the official language of the country.

\section{THE ROLE OF THE NATIONAL ASSEMBLY IN THE ELECTORAL PROCESS}

Generally, the Constitution accords the National Assembly the overall responsibility for law making in the country. It is the supreme legislative authority. The Constitution (s 86) provides that 'subject to the provisions of this Constitution, parliament shall have the power to make laws for the peace, order and good government of Botswana'. Thus, the National Assembly is constitutionally empowered to legislate for the country without qualification as to subject matter or locality. However, the exercise of this legislative power is subject to the Constitution so laws passed by the National Assembly should not contravene the Constitution or any of its provisions. In the case of Dow the Judge President of the Court of Appeal, Justice Amissah, authoritatively observed that the Constitution is the supreme law of the country.

The supremacy of the Constitution means that any law passed by Parliament that is contrary to the Constitution, including a law relating to elections or regulating the electoral process, is invalid or unconstitutional. This principle has been upheld in a number of court decisions. To date, it should be noted, no legislative instrument on electoral process has been declared unconstitutional.

It is noteworthy that pursuant to the Constitution the Legislature in Botswana has discharged its function of enacting laws for the conduct of elections. In other words, since independence Parliament has exercised the necessary oversight in the conduct of elections and its legislative activity has ensured, at least for now, their smooth running and conduct. Below is an examination of the various laws relating to elections.

\section{THE ELECTORAL ACT, CAP 02:07}

The main legislative initiative of the National Assembly in Botswana for the conduct of elections is the Electoral Act No 38, 1968, now cap 02:07. ${ }^{3}$ Its preamble provides that it is to 'consolidate certain laws relating to elections of the National Assembly

3 The Act has been amended several times. For instance, see Electoral (Amendment) Acts Nos 49/1974 and 6/1999. 
and Councils; for the qualifications and registration of voters; for the conduct of such elections and for other purposes in relation to such elections'.

One of the primary features of the Electoral Act relates to the role of the secretary (Constitution s65A) to the Independent Electoral Commission (IEC) (s 66(1)). According to the Act, the secretary shall, subject to the supervision of the commission, 'exercise general direction and supervision over the registration of voters; exercise general direction and supervision over the administrative conduct of elections and enforce on the part of all election officers fairness, impartiality and compliance with the provision of the Act; issue to election officers and registration officers such instructions as he[/ she] may deem fit to ensure effective execution of the provisions of the Act; and exercise and perform all other power conferred and imposed upon him[/ her] by the Act' (Electoral Act s 3(a)-(d)). The secretary is the main administrator responsible for the daily running of elections. In discharging these functions, he or she should ensure that elections are conducted fairly and impartially. This means all individuals and organisations or political parties involved or participating in elections should be treated fairly, equally and without bias (Nsereko 2001, pp 122-3).

A fair and impartially conducted election is very important to any electoral process. It engenders confidence in the electoral system and ensures that voters and political parties alike accept the results. An election that is not tainted by unfairness or bias legitimises the entire electoral process. Absence of independence and impartiality may give the losers, even if they really have no support, grounds for questioning the outcome and justify their resorting to extralegal methods of opposing the legitimacy of the government that comes to power as a result of such an election (Nsereko 2001, pp 123-4). Therefore, the secretary to the IEC must manifest fairness and impartiality in the conduct of the elections. He or she must be neutral or not be seen to be supporting, directly or indirectly, any particular political party or organisation.

In order to ensure the independence of the secretary the Constitution gives him or her security of tenure. Section 66(7) provides that 'a person holding office as Secretary shall vacate that office on attaining the age of 65 years or such other age as may be prescribed by an Act of Parliament'. Further, the secretary can only be removed from office because of inability to perform the functions of his/her office caused by 'infirmity of body or mind or any other cause', or for misbehaviour (s 66(8)).

Where the president considers that the secretary should be removed from office he/she must appoint a tribunal to investigate the matter (s 66(9)(a)). The tribunal shall consist of a chairperson and no fewer than two members who hold or have held high judicial office. The tribunal must then report to the president, advising him/her whether or nor to remove the secretary from office (s 66(9)(b)). 
If the tribunal advises the president that the secretary should be removed the president must remove him/her (s 66(10)). This strict mechanism for removal of the secretary from office is intended to ensure that he/she is independent and impartial in the administration and conduct of elections. It is also meant to ensure that he/she performs his/her functions without fear or favour.

Despite all these mechanisms teething problems still affect perceptions of the independence and impartiality of the secretary of the IEC. The fact that the secretary is now responsible to the IEC not to the Office of the President has not allayed doubts about his autonomy. The main concern relates to the method of appointment of the secretary - which, in terms of the Constitution (s 66(2)), is done by the president. In making the appointment, the president is not subject to any control, even that of the National Assembly. Also, there is no criterion for the appointment of the secretary except the qualifications that he or she is a citizen and has no previous conviction involving dishonesty and insolvency or bankruptcy (s 66(4)(a)-(c)). This means that it is entirely possible for the president to appoint a friend, political associate, or anybody who toes the same political line as he or she does. It is therefore important that the president's role in the appointment of the secretary should be regulated by a representative authority such as the National Assembly.

The other factor is that the Office of the Secretary has no independent budget for conducting elections or for administrative expenses. It is financed through the budget of the Office of the President. This financial or budgetary dependence on the Office of the President also compromises the independence and impartiality of the secretary. It is submitted that a budget approved and regulated by Parliament would go a long way towards remedying the situation and instilling confidence and faith in the electoral process.

Other features of the Electoral Act include provisions relating to entitlement to vote, polling procedures, regulation of election expenses and election agents, outlawing of certain corrupt and illegal practices such as undue influence and bribery of voters, impersonation and treating (entertaining or giving a person payment for purposes of corruptly influencing him/her to vote in a particular manner or not to vote in an election - Electoral Act, s 90(a) and (b)), election petitions, offences, and sanctions for contravening electoral laws and regulations, and other miscellaneous details such as registration of party symbols and colours. All these are meant to ensure a robust legal regime for the conduct of elections.

\section{COUNCIL ELECTION LEGISLATION}

Apart from the Electoral Act, which governs the election of members of the legislature, the National Assembly has also promulgated the Local Councils 
Elections Act (Laws of Botswana Chapter 40:03). The Local Councils Elections Act was enacted in 1966 and came into effect in June of that year. Its main aim is to lay down provisions in relation to elections to local councils. According to the Act (s 2), local council election means an election of members to a district council, city or town council. The Act adopts certain provisions of the Electoral Act with respect to the election of council members, particularly Part IX, which deals with corrupt and illegal practices, and Part X, which regulates election petitions. This means that all issues of corruption and illegal practice and all petitions relating to the election of members of the legislature mutatis mutandis apply to the election of members of local councils. These offences include, inter alia, impersonation, treating, undue influence and bribery of voters, electoral malpractice, irregularities and election petitions.

It is worth noting that, at council level, there have been court cases involving corrupt and illegal practices and petitions about irregularities (Otlhogile 1994, p 222). In Sifo $v$ Gabanapelo (1981 BLR 163) concerning local council elections for Gumare held in 1979, the petitioner unsuccessfully challenged the election of the respondent as a councillor for Gumare. His case was that the respondent had not been properly nominated in accordance with Regulation 6(1) because his proposer, seconder, and supporter were from a different polling district, which fact he had brought to the attention of the police station commander in Shakawe, who, in turn, informed the returning officer. The returning officer had told him that should he win the election this anomaly would be disregarded. He, however, lost. The Court ruled that according to s 138 of the Electoral Act it could not set aside the results of an election because of any mistake or non-compliance with the provisions of Parts VI and VII of the Electoral Act or if such a mistake or noncompliance did not affect the results of the election because elections were free, fair and conducted by secret ballot which reflected the will of the people.

It should be observed that in terms of the Act a general election must be held to elect members of every local council whenever Parliament is dissolved.

Section 31 of the Electoral Act provides that the president shall issue a writ of election for a general election to the National Assembly or for a by-election to fill a vacancy created by the death, resignation, or other cause, of a member of the National Assembly. The writ should be addressed to the returning office of each constituency for which a member is returned fixing the place, date and times when the returning officer should receive nominations and the date of the election. In terms of the Local Councils Elections Act, general elections of local council members should take place at the same time as general elections for the National

$4 \quad$ See also Dithebe v Mafoko Misca 165 of 1987. 
Assembly, thus obviating unnecessary duplication of the costs involved in the running of the elections. The Local Councils Elections Act has been used to administer council elections since independence and has ensured that these elections are or have been run smoothly and fairly.

\section{PARLIAMENTARY OVERSIGHT THROUGH CONSTITUTIONAL AMENDMENTS}

Another legislative attempt to oversee the electoral process in the country has been through amendments to the Constitution and attendant legislation. These have been amendments of those provisions that have adversely affected the proper administration of the elections in order to bring them in tune with modern times and address the concerns of the electorate.

\section{Supervision and Administration of Elections}

The Constitution empowers the Public Service Commission, members of which are appointed by the president, to designate a person who is already a public officer as the Supervisor of Elections. For many years the Public Service Commission designated the permanent secretary to the president as the supervisor. This effectively meant that the supervisor conducted elections from the Office of the President, thereby compromising his much needed independence (Nsereko 2001, p 124). In fact, the supervisor himself acknowledged this anomaly and recommended that the Office of the Supervisor of Elections be removed from the Office of the President and given to a public officer who is not part of that office (Government Printer 1984; Nsereko 2001).

In 1997 Parliament, responding to the recommendation, amended the Constitution by means of the Constitutional (Amendment) Act 18, replacing the supervisor of elections with the secretary to the Independent Electoral Commission.

Parliament also amended the Constitution to establish the IEC. The IEC consists of a chairman who is a judge of the High Court, a legal practitioner, and five other persons who are 'fit, proper and impartial' and are appointed from a list of persons recommended by the All Party Conference, a meeting of all registered parties convened from time to time by the Minister of Presidential Affairs and Public Administration (s 65A(1)(a)-(c)).

The members of the IEC are appointed by the Judicial Service Commission (JSC), an independent body responsible for the appointment of members of the judiciary (Constitution s 103) with the intention of ensuring the IEC's independence. 
The problem is that, apart from a representative of the Law Society of Botswana all members of the JSC have a close relationship with the executive branch of government and almost all of them are directly or indirectly appointed to their positions by the president. Such members include the chief justice, who is the chairman; the president of the Court of Appeal; the attorney general, the chairman of the Public Service Commission and a person of 'integrity and experience' who is not a legal practitioner and is appointed to the JSC by the president (s 103; s 103 (1)(a)-(f)). This involvement of the executive potentially compromises the independence of these members of the JSC, at least from the viewpoint of the public and other people interested in elections. Notwithstanding the above concerns, the fact that Parliament established the IEC clearly demonstrates the role it can play in ensuring that the electoral system is free and fair.

\section{Voting Age}

At independence, the Constitution (s 67(1)(b)) provided for a voting age of 21 but with the passage of time, there were concerns that this excluded a large number of citizens from exercising their right to vote. There were two divergent arguments. On the one hand, opponents of the 21-year limit argued that the voting age should be reduced to 18 because 18-year-olds are capable of making mature political decisions and that many of them worked and paid taxes. On the other hand, supporters of the status quo argued that 18 -year-olds are immature and cannot make proper political decisions.

The matter was the subject of a referendum in 1997 and the consensus was that the voting age should be reduced to 18 . Parliament duly amended the Constitution (s 67(1)(b)).

\section{Extension of Voting Rights to Citizens Resident Abroad}

Another area in which Parliament exercised its oversight was in extending the right to vote to citizens of Botswana who are resident abroad. Previously only citizens who resided in the country were eligible to vote (s 67(1)). The matter was brought to the High Court in the case of Botswana National Front and Others $v$ Attorney General (BLR 1994, p 385).

In this case the applicants sought the nullification of the voters' roll for the 1994 elections and called upon the Court to order the Supervisor of Elections to put in place a method of registration and voting for all citizens outside of Botswana before the general election of 1994; alternatively, to declare an election procedure that did not accommodate two of the applicants (who were Botswana citizens 
resident in South Africa) and other citizens entitled to vote in terms of s 67 of the Constitution to be in breach of that section. It also asked the Court to declare the Writ of Elections for 1994 announced by the President to be stayed, alternatively rescinded, pending the putting in place of the procedure for the registration of the two applicants, other mine workers in South Africa and other citizens resident outside the country. The Court dismissed the application and ordered that the elections be held as scheduled since the applicants had not given the respondent notice of the intended application, as required by law. Thus the case was decided on a mere technicality.

Despite this decision the opposition parties and other interested parties continued to press for the extension of voting rights to citizens resident abroad. During the referendum of 1997 voters supported the extension of universal suffrage to non-resident citizens. Accordingly, Parliament amended the Constitution (s 67(3)(b)) to state that ' $\ldots$ in the case of a person who is not resident in Botswana and is unable to register in person at such place as may be prescribed by parliament, registration at such place shall be treated as registration in the constituency in which he last resided or in which he was born in Botswana'.

This clause has been reinforced by the Electoral Act to ensure its practical application in the registration of foreigners abroad. The Electoral Act (s 8(A)(2)) states that 'the Secretary shall cause a notice to be published in a foreign newspaper in a foreign county circulating in the area of the country where citizens of Botswana are resident calling upon every citizen entitled to be registered as a voter in terms of the Act to apply for registration.' As a result of the amendment, many citizens who live outside the country exercised their right to vote in the 1999 and 2004 general elections.

\section{CONCLUSION}

The role of Parliament in ensuring that the electoral process in any country is free, fair and participatory cannot be overemphasised. In Botswana, the National Assembly is the only law-making authority. As in many countries, it is specifically given the power to make laws for peace, order, and good government. Pursuant to theses powers, the Botswana legislature has used its oversight role to legitimise elections and, indeed, democracy in the country.

The enactment of the Electoral Act with respect to the electoral process and administration was the culmination of its law-making role. The Act has, since the first elections after independence, smoothly regulated the electoral process. It has also been amended from time to the time to ensure that it meets emerging circumstances and challenges. Perhaps also important have been various constitutional amendments relating to the establishment of the IEC, the secretary 
to the IEC, the reduction of the voting age and the extension of voting rights to Botswana citizens resident residing outside the country.

It is submitted that these and other legislative initiatives have ensured that the vast majority of citizens enjoy and exercise their democratic right to vote and anchor the country's democratic principles in a firm base.

\section{- REFERENCES -}

Constitution of Botswana, Cap 01:01.

Government Printer. 1984. Report to the Minister of Public Service and Information on the General Election, 1984. Gaborone.

Nsereko, D D. 2001. Constitutional Law in Botswana. Gaborone: Pula Press.

Otlhogile, B. 1994. 'Judicial Intervention in the Election Process: Botswana's Experience'. CILSA 27.

Roberts, M, M Bratton, Y D Davids \& C Africa. 2000. Public Opinion and the Consolidation of Democracy in Southern Africa: An Initial Review of Key Findings of the Southern African Democracy Barometer. Southern African Democracy Barometer. 